\title{
The comparison of propylene glycol and glycerol as feed additives in early lactation of high producing dairy cows
}

\author{
A. Pechová1,5, P. Pečínka ${ }^{2}$, J. Kudrnáčová ${ }^{3}$ and L. Pavlata ${ }^{4}$ \\ 1 University of Veterinary and Pharmaceutical Sciences, Department of Biochemistry and Biophysics, \\ Faculty of Veterinary Hygiene and Ecology, Palackého 1/3, Brno, Czech Republic \\ ${ }^{2}$ Private Veterinary Surgeon, Blažíčkova 1406/31, Ždár nad Sázavou, Czech Republic \\ ${ }^{3}$ Private Veterinary Surgeon, 5.května 846, Lomnice nad Popelkou, Czech Republic \\ ${ }^{4}$ Mendel University in Brno, Department of Nutrition and Forage Production, Agronomic Faculty, Zemědělská 1, Brno, Czech Republic
}

KEY WORDS: energy metabolism, rumen fermentation, liver, blood, milk yield, dairy cows

Received: 13 June 2014

Revised: 4 November 2014

Accepted: 28 November 2014

${ }^{5}$ Corresponding author: e-mail: pechovaa@vfu.cz

\begin{abstract}
The aim of this study was to compare the antiketogenic effect of glycerol and propylene glycol after parturition. Two experiments were carried out on 36 Holstein cows. In each experiment there were 18 dairy cows receiving daily $300 \mathrm{ml}$ of propylene glycol and either 500 or $1000 \mathrm{ml}$ of glycerol during the first month of lactation. Blood was taken on weeks 1, 2, 3, and rumen fluid, on week 3 after parturition. A similar antiketogenic effect of $300 \mathrm{ml}$ of propylene glycol and $500 \mathrm{ml}$ of glycerol was observed. Although no negative effects of high doses of glycerol $\left(1000 \mathrm{ml} \cdot \mathrm{d}^{-1}\right)$ on metabolism, ruminal fermentation, or liver parenchyma were found, there were no additional positive effects over the $500 \mathrm{ml}$ dose. The results indicate that glycerol is an appropriate alternative for cattle to prevent energy deficiency in the early lactation period, while increasing the daily glycerol dose from 500 to $1000 \mathrm{ml}$ has no beneficial effect.
\end{abstract}

\section{Introduction}

Meeting the nutritional requirements of highproducing dairy cows is a challenge, particularly in the calving period. Typically, feed intake during the first 5 weeks of lactation is insufficient to match the increasing energy demands of lactation (Goff, 2006). To minimize the negative energy balance, farmers use glucose precursors such as calcium propionate, propylene glycol and glycerol in different forms. Propylene glycol has been used for a long time to prevent energy deficiency in high-producing dairy cows and its effect has been well documented (Nielsen and Ingvartsen, 2004). Glycerol has been known as an efficient antiketogenic preparation since the 1950s and its functions have been described in detail by
Fisher et al. (1973). Further studies on its use for dairy cows were almost stopped in the 1980s due to low cost-effectiveness and limited availability on the market. At present, thanks to biodiesel production, large quantities of glycerol $(10 \%$ by weight of processed oil) will become available at a much lower price. This has revived interest in glycerol for treatment of ketosis in ruminants and as a feed additive for fresh cows (Fischer et al., 1973; DeFrain et al., 2004; Kass et al., 2013) or as a substitute for maize or barley (Kass et al., 2012; Wilbert et al., 2013). The results of experimental work with supplementation of glycerol and propylene glycol in fresh cows differ. Lomander et al. (2012) did not find a positive effect of glycerol or propylene glycol in Swedish dairy herds, but Adamski et al. (2011) found beneficial effects of 
these supplements in Simmental cows. For Jersey cows at the top of lactation, Wilbert et al. (2013) recommended crude glycerine as a good alternative energy feedstuff at a dose of up to $120 \mathrm{~g} \cdot \mathrm{kg}^{-1}$ dry matter (DM), but this study did not evaluate the composition of rumen juice. The effects of substituting maize with glycerol at different levels on rumen fermentation were studied by Abo El-Nor et al. (2010). They found negative effect on some rumen microbes starting from a glycerol concentration of $36 \mathrm{~g} \cdot \mathrm{kg}^{-1} \mathrm{DM}$ and decreased digestibility of NDF from a glycerol concentration of $72 \mathrm{~g} \cdot \mathrm{kg}^{-1} \mathrm{DM}$. Changes in the rumen volatile fatty acid profile occurred from a glycerol concentration of $36 \mathrm{~g} \cdot \mathrm{kg}^{-1}$ DM ( $\uparrow$ butyrate and valerate, $\downarrow$ acetate) .

On the basis of experimental results, glycerol can be used instead of propylene glycol as a preventive measure for the development of ketosis and fat-cow syndrome in the post parturient period. Glycerol in comparison with propylene glycol is more palatable for cows and, therefore, may be more effective as it can increase dry matter intake in fresh cows. On the other hand, glycerol can be metabolized in the rumen to butyrate, which then increases the amount of ketone bodies in the blood.

The aim of our work is to compare these two additives in a field study based on evaluation of metabolic profile, rumen juice and milk production.

This study had two objectives. The first was to compare the effect of energetically equivalent doses of propylene glycol and crude glycerol as feed additives on energy metabolism, ruminal fermentation and milk yield of dairy cows in early lactation. The second was to evaluate a double dose of crude glycerol with a lower dose of propylene glycol with the aim to find if the double dose of crude glycerol is more effective in prevention of energy deficiency and also to evaluate the potential adverse effect on rumen fermentation or liver parenchyma.

\section{Material and methods}

A commercial dairy herd with 630 lactating Holstein Friesian dairy cows located in the Moravian Highlands was used. The herd was housed in a freestall barn, fed on a total mixed ration (TMR), and milked twice daily. The two experiments comparing the effect of application of $500 \mathrm{ml}$ and $1000 \mathrm{ml}$ glycerol with $300 \mathrm{ml}$ propylene glycol as a feeding additive during the first three weeks of lactation were carried out in two consecutive periods as a field study.

\section{Experiment 1}

Eighteen cows were used in this experiment: the experimental group $(\mathrm{G} 1, \mathrm{n}=9)$ and control group $(\mathrm{P} 1, \mathrm{n}=9)$. The cows were divided into these groups using the analogous pairs method according parity (G1: $2.11 \pm 0.74 ; \mathrm{P} 1: 2.56 \pm 1.26$ ), milk yield in previous lactation (G1: $11078.14 \pm 1154.92 \mathrm{~kg}$; P1: $11093.14 \pm 1802.60 \mathrm{~kg}$ ) and body condition score (G1: $3.83 \pm 0.26 ; \mathrm{P} 1: 3.9 \pm 0.19$ ). The body condition score was assessed one week before parturition according the method using a 5-point scale (Wildman et al., 1982). The experiment started on the day of parturition. Both groups of cows were given identical TMR, the composition of which is shown in Table 1. Immediately after parturition the cows received an oral drench containing either $300 \mathrm{ml}$ of propylene glycol or $500 \mathrm{ml}$ of crude glycerol (80.4\% glycerol, $3.5 \%$ ash, $10.7 \%$ water, $0.18 \%$ methanol, $5.2 \%$ non-glycerol organic matter). Subsequently for the next 20 days, the same doses were administered as part of the TMR diet given ad libitum. Doses of additives were established according to combustion heat values for crude glycerol $\left(13.98 \mathrm{MJ} \cdot \mathrm{kg}^{-1}\right)$ and propylene glycol $\left(23.69 \mathrm{MJ} \cdot \mathrm{kg}^{-1}\right)$, which were determined in the laboratory.

Table 1. The composition of the diets (Experiments 1 and 2)

\begin{tabular}{|c|c|c|}
\hline Experiment & 1 & 2 \\
\hline \multicolumn{3}{|l|}{ Ingredient, $\mathrm{g} \cdot \mathrm{kg}^{-1} \mathrm{DM}$} \\
\hline grass silage & 213 & - \\
\hline clover silage & - & 163 \\
\hline maize silage & 138 & 196 \\
\hline beet pulp & 95 & 95 \\
\hline wet brewer's draft & 68 & 68 \\
\hline production mixture $^{1}$ & 412 & 418 \\
\hline hay & 52 & 52 \\
\hline straw & 22 & 10 \\
\hline \multicolumn{3}{|l|}{ Chemical composition, $\mathrm{g} \cdot \mathrm{kg}^{-1} \mathrm{DM}$} \\
\hline dry matter, $\mathrm{g} \cdot \mathrm{kg}^{-1}$ & 417.7 & 447.0 \\
\hline crude protein & 185.2 & 176.8 \\
\hline undegradable protein & 61.7 & 61.0 \\
\hline rumen degradable protein & 123.5 & 115.9 \\
\hline netto energy of lactation, $\mathrm{MJ}, \mathrm{g} \cdot \mathrm{kg}^{-1} \mathrm{DM}$ & 6.7 & 6.7 \\
\hline acid detergent fibre & 197.5 & 201.2 \\
\hline neutral detergent fibre & 346.3 & 317.1 \\
\hline fat & 47.5 & 47.0 \\
\hline $\mathrm{Ca}$ & 11.0 & 11.5 \\
\hline$P$ & 5.9 & 5.7 \\
\hline $\mathrm{Na}$ & 6.4 & 6.2 \\
\hline$K$ & 14.3 & 14.0 \\
\hline $\mathrm{Mg}$ & 5.9 & 5.6 \\
\hline
\end{tabular}

${ }^{1}$ composition of production mixture, \%: rapeseed cake 20 , soya meal 20 , barley meal 20 , wheat meal $20 \%$, maize meal 15 


\section{Experiment 2}

Experiment 2 was carried out after the completion of the first. Eighteen cows were included in the experiment: the experimental group $(\mathrm{G} 2, \mathrm{n}=9)$ and the control group (P2, n =9). The cows were divided into these groups using the method of analogous pairs according parity (P2: $2.22 \pm 1.03 ; \mathrm{G} 2: 2.33 \pm 1.05)$, milk yield in previous lactation $(\mathrm{P} 2: 11042 \pm 2144 \mathrm{~kg}$; $\mathrm{G} 2: 11015 \pm 2240 \mathrm{~kg}$ ) and body condition score (P2: $3.86 \pm 0.27 ; \mathrm{G} 2: 3.83 \pm 0.28)$. Body condition score was assessed one week before parturition using a 5-point scale (Wildman et al., 1982).

The experiment started on the day of parturition. Both groups of cows were given an identical TMR, the composition of which is shown in Table 1. Group $\mathrm{P} 2$ received $300 \mathrm{ml} / \mathrm{d} / \mathrm{head}$ of propylene glycol and group $\mathrm{G} 2$ received $1000 \mathrm{ml} / \mathrm{d} /$ head of crude glycerol $(80.4 \%$ glycerol, $3.5 \%$ ash, $10.7 \%$ water, $0.18 \%$ methanol, 5.2\% non-glycerol organic matter). Immediately after parturition, the cows received an oral drench containing either $300 \mathrm{ml}$ of propylene glycol or $1000 \mathrm{ml}$ of crude glycerol (80.4\% glycerol, $3.5 \%$ ash, $10.7 \%$ water, $0.18 \%$ methanol, $5.2 \%$ non-glycerol organic matter). Subsequently for the next 20 days, the same doses were administered as part of the TMR diet given ad libitum.

\section{Collection of samples and chemical analyses}

In both experiments, rumen fluid was taken by rumenocentesis (Kleen et al., 2004) 3-4 h after the morning feeding on day $21 \pm 1$ after parturition. Volatile fatty acids (VFA), ammonia and $\mathrm{pH}$ were determined in rumen fluid. Blood samples were collected 3-4 h after the morning feeding on day $7 \pm 1$, $14 \pm 1$ and $21 \pm 1$ after parturition. Blood was collected from the vena caudalis mediana into Hemos sampling tubes without any additional anticoagulants for serum examination and with heparin for whole blood examination. A small amount of blood was preserved by sodium fluoride for glucose determination. The following parameters were determined in blood serum: beta-hydroxybutyrate (BHB), nonesterified fatty acids (NEFA), triacylglycerols (TG), cholesterol (Chol), total protein (TP), albumin (Alb), urea (U), aspartate transaminase EC 2.6.1.1 (AST), gamma-glutamyltransferase EC 2.3.2.2 (GMT), lactate dehydrogenase EC 1.1.1.27 (LDH), total bilirubin (Bil). Glucose was measured in fluoride plasma, and ketone bodies were measured in whole blood. Most biochemical parameters were determined by photometric methods using a Cobas Mira automatic analyser. The parameters are sorted by the manufacturers of the tests:
LACHEMA - urea (Urea UV KIN $4 \times 50$, Cat. No. 1307017), total bilirubin (BIL 100, Cat. No. 1105309), GMT (GMT KIN 100, Cat. No. 1302082), triacylglycerols (TGL $4 \times 100$, Cat. No. 1312983

BioVendor - glucose ( ${ }^{\mathrm{L} G l u k o s a}$, Cat. No. 11601), total protein ('Protein total, Cat. No. 12751), total cholesterol $\left({ }^{\mathrm{L} C h o l e s t e r o l, ~ C a t . ~ N o .10851, ~}\right.$ AST ( ${ }^{\mathrm{L} A S T}$, Cat. No. 10351), LDH ( ${ }^{\mathrm{L} L D H}$, Cat. No. 12352)

Human - albumin (ALBUMIN liquicolor, Cat. No. 10560)

RANDOX - nonesterified fatty acids (NEFA, Cat. No. FA 115), $\beta$-hydroxybutyrate (RANBUT, Cat. No, RB 1008).

Total ketone bodies (acetone, acetoacetic acid, isopropanol, beta-hydroxybutyric acid) and oxidized ketone bodies (acetone, acetoacetic acid) were determined in the whole blood by gas chromatography (Hradecký et al., 1978), using an Agilent 6820 GC System (Agilent Technologies, USA). Concentrations of volatile fatty acids (acetic, propionic, butyric and valeric acid) in the rumen fluid were determined by gas chromatography (Cottyn and Boucque, 1968), using an Agilent 6820 GC System (Agilent Technologies, USA). The ammonia concentration was determined by Berthelot's photometric reaction (Chaney and Marbach, 1962).

The health status of cows was monitored by a local veterinary surgeon. Data on milk yield and composition during first three months of lactation were obtained from monthly milk yield recording. Milk composition was analysed by an infrared absorption analyser.

\section{Statistical analysis}

The results were evaluated statistically using the $F$ test for assessment of the variance of individual sets and using the dependent Student's t-test for sets with equality/non-equality of variance, according to the results. The results are quoted as a mean value with standard deviation. The tests were performed using MS-Excel ${ }^{\circledR}$ software (Microsoft Corp., Inc., 2010).

\section{Results}

\section{Experiment 1}

In the first three weeks of lactation, both groups of cows showed energy deficiency (Table 2). Energy deficiency in cows is apparent from a decreased concentration of glucose that is under the reference limit of $3.0 \mathrm{mmol} \cdot 1^{-1}$ (Hofirek et al., 2009) and increased concentration of total ketone bodies above 
Table 2. Selected indicators of metabolism during 3 weeks after parturition in group receiving $500 \mathrm{ml}$ of glycerol $(\mathrm{G} 1, \mathrm{n}=9)$ or $300 \mathrm{ml}$ of propylene glycol $(P 1, n=9)$

\begin{tabular}{|c|c|c|c|c|}
\hline \multirow{2}{*}{ Indices } & \multirow{2}{*}{ Group } & \multicolumn{3}{|l|}{ Week } \\
\hline & & $1^{\text {st }}$ & $2^{\text {nd }}$ & $3^{\text {rd }}$ \\
\hline \multicolumn{5}{|l|}{$\mathrm{mmol} \cdot \mathrm{l}^{-1}$} \\
\hline \multirow[t]{2}{*}{ glucose } & $\mathrm{G} 1$ & $2.84 \pm 0.37$ & $2.64 \pm 0.43$ & $2.82 \pm 0.50$ \\
\hline & $\mathrm{P} 1$ & $2.93 \pm 0.42$ & $2.77 \pm 0.22$ & $2.83 \pm 0.34$ \\
\hline \multirow[t]{2}{*}{ NEFA } & $\mathrm{G} 1$ & $0.71 \pm 0.32$ & $0.82 \pm 0.42$ & $0.74 \pm 0.28$ \\
\hline & $\mathrm{P} 1$ & $0.91 \pm 0.45$ & $0.94 \pm 0.31$ & $0.72 \pm 0.16$ \\
\hline \multirow{2}{*}{$\begin{array}{l}\text { beta-hydroxy- } \\
\text { butyrate }\end{array}$} & $\mathrm{G} 1$ & $1.08 \pm 0.43$ & $1.25 \pm 0.44$ & $0.97 \pm 0.36$ \\
\hline & $\mathrm{P} 1$ & $0.87 \pm 0.38$ & $1.23 \pm 0.62$ & $0.73 \pm 0.14$ \\
\hline \multirow{2}{*}{$\begin{array}{l}\text { oxidized ketone } \\
\text { bodies }\end{array}$} & $\mathrm{G} 1$ & $0.23 \pm 0.11$ & $0.20 \pm 0.10$ & $0.13 \pm 0.04$ \\
\hline & $\mathrm{P} 1$ & $0.23 \pm 0.06$ & $0.21 \pm 0.13$ & $0.10 \pm 0.04$ \\
\hline \multirow{2}{*}{$\begin{array}{l}\text { total ketone } \\
\text { bodies }\end{array}$} & $\mathrm{G} 1$ & $1.42 \pm 0.58$ & $1.64 \pm 0.63$ & $1.21 \pm 0.52$ \\
\hline & $\mathrm{P} 1$ & $1.27 \pm 0.42$ & $1.49 \pm 0.46$ & $1.25 \pm 0.46$ \\
\hline \multirow[t]{2}{*}{ triacylglycerols } & G1 & $0.25 \pm 0.12$ & $0.35 \pm 0.17$ & $0.35 \pm 0.20$ \\
\hline & $\mathrm{P} 1$ & $0.27 \pm 0.08$ & $0.28 \pm 0.11$ & $0.27 \pm 0.09$ \\
\hline \multirow[t]{2}{*}{ cholesterol } & $\mathrm{G} 1$ & $2.29 \pm 0.40$ & $3.34 \pm 0.70$ & $4.17 \pm 0.74$ \\
\hline & $\mathrm{P} 1$ & $2.46 \pm 0.25$ & $3.38 \pm 0.69$ & $4.01 \pm 0.75$ \\
\hline \multirow[t]{2}{*}{ urea } & $\mathrm{G} 1$ & $4.08 \pm 0.79$ & $4.27 \pm 0.63$ & $4.42 \pm 0.79$ \\
\hline & $\mathrm{P} 1$ & $4.03 \pm 0.58$ & $3.84 \pm 0.45$ & $4.28 \pm 0.79$ \\
\hline \multicolumn{5}{|l|}{$\mu \mathrm{mol} \cdot l^{-1}$} \\
\hline \multirow[t]{2}{*}{ total bilirubin } & $\mathrm{G} 1$ & $5.54 \pm 1.50$ & $6.34 \pm 2.51$ & $5.73 \pm 1.10$ \\
\hline & $\mathrm{P} 1$ & $6.80 \pm 2.51$ & $7.78 \pm 1.95$ & $5.82 \pm 1.72$ \\
\hline \multicolumn{5}{|l|}{$\mathrm{g} \cdot \mathrm{I}^{-1}$} \\
\hline \multirow[t]{2}{*}{ total protein } & $\mathrm{G} 1$ & $64.41 \pm 3.86$ & $70.20 \pm 6.10$ & $71.53 \pm 3.57^{*}$ \\
\hline & $\mathrm{P} 1$ & $69.10 \pm 5.20$ & $72.32 \pm 6.51$ & $76.32 \pm 4.24$ \\
\hline \multirow[t]{2}{*}{ albumin } & $\mathrm{G} 1$ & $32.75 \pm 1.99$ & $33.95 \pm 1.82$ & $35.19 \pm 3.41$ \\
\hline & $\mathrm{P} 1$ & $32.30 \pm 1.87$ & $32.74 \pm 2.47$ & $33.29 \pm 2.58$ \\
\hline \multicolumn{5}{|l|}{$\mu \mathrm{kat} \cdot \mathrm{I}^{-1}$} \\
\hline \multirow[t]{2}{*}{ AST } & $\mathrm{G} 1$ & $1.97 \pm 0.53$ & $1.98 \pm 0.72$ & $1.86 \pm 0.44$ \\
\hline & $\mathrm{P} 1$ & $2.02 \pm 0.47$ & $1.93 \pm 0.35$ & $1.82 \pm 0.48$ \\
\hline \multirow[t]{2}{*}{ GMT } & $\mathrm{G} 1$ & $0.32 \pm 0.07^{\star \star}$ & ${ }^{*} 0.35 \pm 0.13$ & $0.38 \pm 0.15$ \\
\hline & $\mathrm{P} 1$ & $0.48 \pm 0.10$ & $0.45 \pm 0.11$ & $0.44 \pm 0.14$ \\
\hline \multirow[t]{2}{*}{$\mathrm{LDH}$} & $\mathrm{G} 1$ & $35.91 \pm 6.38$ & $43.23 \pm 10.47$ & $41.51 \pm 8.41$ \\
\hline & $\mathrm{P} 1$ & $37.65 \pm 6.17$ & $38.91 \pm 6.88$ & $36.31 \pm 9.45$ \\
\hline
\end{tabular}

$1.0 \mathrm{mmol} \cdot \mathrm{1}^{-1}$ (Hofírek et al., 2009) in both groups during whole experimental period. The extent of mobilization of body lipids is seen from the increased concentration of NEFA in blood serum above the values recommended for fresh cows, $0.7 \mathrm{mmol} \cdot 1^{-1}$ (Stengarde et al., 2008). The concentration of NEFA was increased by similar extents in both groups during the entire three weeks of the experiment. Energy metabolism parameters did not show any significant differences between the groups. Similar degrees of liver steatosis caused by energy deficiency were observed in both experimental groups. Increased activity of AST $\left(1.4 \mu \mathrm{kat} \cdot \mathrm{1}^{-1}\right.$; Pechová et al., 1997), as well as increased level of LDH (29 $\mu \mathrm{kat} \cdot \mathrm{l}^{-1}$; Pechová et al., 1997) and total bilirubin (5.12 $\mu \mathrm{mol} \cdot \mathrm{1}^{-1}$; Hofírek et al., 2009) were observed in both groups throughout the entire experiment.
A significant difference between groups was observed only in the first week of lactation in GMT activity, which was lower in group G1 in comparison with $\mathrm{P} 1$, although the activity of this enzyme did not reach the reference value $\left(0.52 \mu \mathrm{kat} \cdot \mathrm{I}^{-1}\right.$, Hofírek et al., 2009) in any cow from either group. Total protein was in the reference range $\left(60-80 \mathrm{~g} \cdot 1^{-1}\right.$; Hofirek et al., 2009) throughout the experiment. Significantly lower concentrations of total protein in group G1 were found in week three.

The results of ruminal fluid analysis in the $3^{\text {rd }}$ week of lactation are shown in Table 3. Total acidity, as well as the concentration of $\mathrm{NH}_{3}$, total VFA, propionic acid, butyric acid and valeric acid in the rumen fluid were numerically higher in cows from group $\mathrm{G} 1$, whereas $\mathrm{pH}$ and acetic acid concentration were lower. However, these differences between groups were not significant. Milk yield and composition were not significantly influenced by treatment (Table 4). The evaluation of milk production up to the third month of lactation shows a smaller decline in the glycerol group ( $96 \%$ in comparison with the first month) than in the propylene glycol group ( $89 \%$ in comparison with the first month).

\section{Experiment 2}

In the first three weeks of lactation, both groups of dairy cows showed mild energy deficiency characterized only by increased concentration of non-

Table 3. Selected indicators of ruminal fermentation 3 weeks after parturition in group receiving $500 \mathrm{ml}$ of glycerol $(\mathrm{G} 1, \mathrm{n}=9)$ or $300 \mathrm{ml}$ of propylene glycol $(P 1, n=9)$ and in group receiving $1000 \mathrm{ml}$ of glycerol $(\mathrm{G} 2, \mathrm{n}=9)$ or $300 \mathrm{ml}$ of propylene glycol $(P 2, n=9)$

\begin{tabular}{|c|c|c|c|c|}
\hline \multirow{2}{*}{ Indices } & \multicolumn{2}{|c|}{ Experiment 1} & \multicolumn{2}{|c|}{ Experiment 2} \\
\hline & group & $3^{\text {rd }}$ week & group & $3^{\text {rd }}$ week \\
\hline \multirow[t]{2}{*}{$\mathrm{pH}$} & $\mathrm{G} 1$ & $6.19 \pm 0.38$ & G2 & $6.26 \pm 0.39$ \\
\hline & $\mathrm{P} 1$ & $6.21 \pm 0.26$ & $\mathrm{P} 2$ & $6.50 \pm 0.27$ \\
\hline \multicolumn{5}{|l|}{$\mathrm{mmol} \cdot \mathrm{I}^{-1}$} \\
\hline \multirow[t]{2}{*}{$\mathrm{NH}_{3}$} & G1 & $10.12 \pm 3.51$ & $\mathrm{G} 2$ & $7.31 \pm 2.59$ \\
\hline & $\mathrm{P} 1$ & $8.89 \pm 2.79$ & $\mathrm{P} 2$ & $5.38 \pm 1.55$ \\
\hline \multirow[t]{2}{*}{ VFA } & $\mathrm{G} 1$ & $115.08 \pm 14.13$ & G2 & $116.22 \pm 21.29$ \\
\hline & $\mathrm{P} 1$ & $119.57 \pm 13.10$ & $\mathrm{P} 2$ & $112.20 \pm 21.01$ \\
\hline \multicolumn{5}{|l|}{$\mathrm{mol} \%$} \\
\hline \multirow[t]{2}{*}{ acetate } & $\mathrm{G} 1$ & $56.19 \pm 3.70$ & $\mathrm{G} 2$ & $61.19 \pm 3.05$ \\
\hline & $\mathrm{P} 1$ & $59.34 \pm 2.41$ & $\mathrm{P} 2$ & $63.10 \pm 2.63$ \\
\hline \multirow[t]{2}{*}{ propionate } & $\mathrm{G} 1$ & $27.58 \pm 3.75$ & $\mathrm{G} 2$ & $23.51 \pm 2.07$ \\
\hline & $\mathrm{P} 1$ & $25.71 \pm 2.49$ & $\mathrm{P} 2$ & $22.69 \pm 2.15$ \\
\hline \multirow[t]{2}{*}{ butyrate } & $\mathrm{G} 1$ & $13.01 \pm 1.04$ & $\mathrm{G} 2$ & $12.39 \pm 1.42$ \\
\hline & $\mathrm{P} 1$ & $12.23 \pm 0.69$ & $\mathrm{P} 2$ & $11.74 \pm 2.20$ \\
\hline \multirow[t]{2}{*}{ valerate } & $\mathrm{G} 1$ & $3.23 \pm 0.49$ & $\mathrm{G} 2$ & $2.91 \pm 0.57$ \\
\hline & $\mathrm{P} 1$ & $2.68 \pm 0.45$ & $\mathrm{P} 2$ & $2.85 \pm 0.58$ \\
\hline
\end{tabular}


Table 4. Milk yield during 3 month after parturition in group receiving $500 \mathrm{ml}$ of glycerol $(\mathrm{G} 1, \mathrm{n}=9)$ or $300 \mathrm{ml}$ of propylene glycol (P1, n = 9)

\begin{tabular}{cllll}
\hline \multirow{2}{*}{ Indices } & Group & \multicolumn{3}{l}{ Month } \\
\cline { 3 - 5 } & & $1^{\text {st }}$ & $2^{\text {nd }}$ & $3^{\text {rd }}$ \\
\hline Milk yield, $\mathrm{kg}$ & $\mathrm{G} 1$ & $47.4 \pm 9.6$ & $48.9 \pm 10.3$ & $45.7 \pm 13.9$ \\
& $\mathrm{P} 1$ & $52.7 \pm 10.3$ & $50.3 \pm 5.1$ & $47.0 \pm 4.7$ \\
$\mathrm{~g} \cdot \mathrm{kg}^{-1}$ & & & & \\
fat & $\mathrm{G} 1$ & $35.4 \pm 6.6$ & $32.4 \pm 4.1$ & $35.1 \pm 6.9$ \\
& $\mathrm{P} 1$ & $36.5 \pm 5.0$ & $34.7 \pm 10.9$ & $30.2 \pm 5.6$ \\
protein & $\mathrm{G} 1$ & $29.5 \pm 2.0$ & $31.4 \pm 1.2$ & $30.3 \pm 1.1$ \\
& $\mathrm{P} 1$ & $29.8 \pm 2.2$ & $32.6 \pm 3.0$ & $32.0 \pm 3.0$ \\
lactose & $\mathrm{G} 1$ & $52.3 \pm 1.1$ & $52.0 \pm 1.7$ & $50.7 \pm 1.3$ \\
& $\mathrm{P} 1$ & $51.4 \pm 0.9$ & $48.3 \pm 9.7$ & $50.4 \pm 1.4$ \\
\hline
\end{tabular}

esterified fatty acids, which were increased in relation to the values recommended for fresh cows, $0.7 \mathrm{mmol} \cdot 1^{-1}$ (Stengarde et al., 2008) in both groups in the first two weeks after parturition. The concentrations of glucose in both groups were within the reference limits during the whole experiment. The concentration of ketone bodies was slightly increased only in the first week after parturition. Subclinical ketoses occurred in about $50 \%$ of dairy cows in the first two weeks after parturition. There were no significant differences between groups in energy metabolism parameters (Table 5). Both groups showed similar degrees of alteration of liver parenchyma without any significant differences. In comparison with reference values, increased activity of AST (1.4 $\mu \mathrm{kat} \cdot 1^{-1}$; Pechová et al., 1997), as well as LDH (29 $\mu \mathrm{kat} \cdot \mathrm{1}^{-1}$; Pechová et al., 1997) and increased level of total bilirubin $\left(5.12 \mu \mathrm{mol} \cdot \mathrm{1}^{-1}\right.$; Hofírek et al., 2009) were observed in both groups throughout the experiment. The total protein concentration increased with time after parturition in both groups and it was always higher in P2 group than in G2, but a significant difference between groups was observed only in week three.

The concentration of total VFA in the rumen fluid as well as the proportion of propionic and butyric acids in total VFA were numerically higher in group G2, whereas acetic acid was lower (Table 3), but these differences were not significant. Milk yield and composition did not differ significantly among treatments (Table 6), except for the significantly higher protein content in group G2 in the first month. The evaluation of milk production up to the third month of lactation showed a lower drop in the glycerol group ( $96 \%$ in comparison with first month) than in the propylene glycol group (90\% in comparison with the first month).
Table 5. Selected indicators of metabolism during 3 weeks after parturition in group receiving $1000 \mathrm{ml}$ of glycerol $(\mathrm{G} 2, \mathrm{n}=9)$ or $300 \mathrm{ml}$ of propylene glycol $(P 2, n=9)$

\begin{tabular}{|c|c|c|c|c|}
\hline \multirow{2}{*}{ Indices } & \multirow[t]{2}{*}{ Group } & \multicolumn{3}{|l|}{ Week } \\
\hline & & $1^{\text {st }}$ & $2^{\text {nd }}$ & $3^{\text {rd }}$ \\
\hline \multicolumn{5}{|l|}{$\mathrm{mmol} \cdot \mathrm{I}^{-1}$} \\
\hline \multirow[t]{2}{*}{ glucose } & $\mathrm{G} 2$ & $3.05 \pm 0.41$ & $3.35 \pm 0.37$ & $3.51 \pm 0.33$ \\
\hline & $\mathrm{P} 2$ & $3.15 \pm 0.28$ & $3.38 \pm 0.27$ & $3.43 \pm 0.22$ \\
\hline \multirow[t]{2}{*}{ NEFA } & G2 & $0.97 \pm 0.36$ & $0.74 \pm 0.20$ & $0.50 \pm 0.14$ \\
\hline & $\mathrm{P} 2$ & $1.03 \pm 0.32$ & $0.71 \pm 0.28$ & $0.66 \pm 0.27$ \\
\hline \multirow{2}{*}{$\begin{array}{l}\text { beta-hydroxy- } \\
\text { butyrate }\end{array}$} & $\mathrm{G} 2$ & $1.05 \pm 0.46$ & $0.91 \pm 0.39$ & $0.65 \pm 0.32$ \\
\hline & P2 & $0.86 \pm 0.30$ & $0.71 \pm 0.29$ & $0.51 \pm 0.14$ \\
\hline \multirow{2}{*}{$\begin{array}{r}\text { oxidized } \\
\text { ketone } \\
\text { bodies }\end{array}$} & G2 & $0.18 \pm 0.07$ & $0.16 \pm 0.06$ & $0.20 \pm 0.10$ \\
\hline & P2 & $0.17 \pm 0.03$ & $0.13 \pm 0.03$ & $0.31 \pm 0.28$ \\
\hline \multirow{2}{*}{$\begin{array}{l}\text { total ketone } \\
\text { bodies }\end{array}$} & $\mathrm{G} 2$ & $1.04 \pm 0.47$ & $1.11 \pm 0.36$ & $0.95 \pm 0.29$ \\
\hline & P2 & $1.13 \pm 0.35$ & $0.83 \pm 0.25$ & $1.57 \pm 1.54$ \\
\hline \multicolumn{2}{|c|}{ triacylglycerols G2 } & $0.10 \pm 0.10$ & $0.10 \pm 0.04$ & $0.11 \pm 0.07$ \\
\hline & $\mathrm{P} 2$ & $0.12 \pm 0.13$ & $0.17 \pm 0.28$ & $0.11 \pm 0.07$ \\
\hline \multirow[t]{2}{*}{ cholesterol } & $\mathrm{G} 2$ & $2.04 \pm 0.39$ & $2.77 \pm 0.61$ & $3.14 \pm 0.88$ \\
\hline & P2 & $1.79 \pm 0.42$ & $2.69 \pm 0.86$ & $3.48 \pm 0.87$ \\
\hline \multirow[t]{2}{*}{ urea } & $\mathrm{G} 2$ & $4.15 \pm 0.70$ & $4.23 \pm 0.66$ & $4.06 \pm 0.81$ \\
\hline & $\mathrm{P} 2$ & $4.39 \pm 0.91$ & $4.06 \pm 1.03$ & $4.61 \pm 0.81$ \\
\hline \multicolumn{5}{|l|}{$\left.\mu \mathrm{mol} \cdot\right|^{-1}$} \\
\hline \multirow[t]{2}{*}{ total bilirubin } & $\mathrm{G} 2$ & $11.50 \pm 5.81$ & $7.73 \pm 2.62$ & $5.94 \pm 1.66$ \\
\hline & $\mathrm{P} 2$ & $12.55 \pm 4.84$ & $9.92 \pm 5.70$ & $6.89 \pm 2.57$ \\
\hline \multicolumn{5}{|l|}{$\mathrm{g} \cdot \mathrm{H}^{-1}$} \\
\hline \multirow[t]{2}{*}{ total protein } & G2 & $68.60 \pm 4.41$ & $71.03 \pm 6.19$ & $72.72 \pm 3.45^{*}$ \\
\hline & P2 & $69.58 \pm 3.98$ & $73.89 \pm 4.88$ & $78.69 \pm 5.85$ \\
\hline \multirow[t]{2}{*}{ albumin } & G2 & $37.03 \pm 1.62$ & $37.04 \pm 1.40$ & $38.59 \pm 5.03$ \\
\hline & $\mathrm{P} 2$ & $36.98 \pm 2.26$ & $39.13 \pm 7.25$ & $39.40 \pm 4.25$ \\
\hline \multicolumn{5}{|l|}{$\mu \mathrm{kat} \cdot \mathrm{r}^{-1}$} \\
\hline \multirow[t]{2}{*}{ AST } & G2 & $2.67 \pm 1.80$ & $2.32 \pm 0.81$ & $1.79 \pm 0.51$ \\
\hline & $\mathrm{P} 2$ & $2.21 \pm 0.75$ & $2.08 \pm 0.52$ & $1.66 \pm 0.24$ \\
\hline \multirow[t]{2}{*}{ GMT } & G2 & $0.45 \pm 0.13$ & $0.47 \pm 0.10$ & $0.54 \pm 0.15$ \\
\hline & P2 & $0.45 \pm 0.20$ & $0.62 \pm 0.55$ & $0.60 \pm 0.45$ \\
\hline \multirow[t]{2}{*}{ LDH } & $\mathrm{G} 2$ & \multirow{2}{*}{\multicolumn{3}{|c|}{$\begin{array}{l}41.15 \pm 6.6945 .91 \pm 14.6742 .76 \pm 11.30 \\
4279+7.354574+15.773961+11.93\end{array}$}} \\
\hline & $\mathrm{P} 2$ & & & \\
\hline
\end{tabular}

${ }^{*} P<0.05$-between groups $\mathrm{G} 2$ and $\mathrm{P} 2$

Table 6. Milk yield during 3 month after parturition in group receiving $1000 \mathrm{ml}$ of glycerol $(\mathrm{G} 2, \mathrm{n}=9$ ) or $300 \mathrm{ml}$ of propylene glycol (P2, $\mathrm{n}=9$ )

\begin{tabular}{cllll}
\hline \multirow{5}{*}{ Group } & \multicolumn{3}{l}{ Month } \\
\cline { 3 - 5 } & & $1^{\text {st }}$ & $2^{\text {nd }}$ & $3^{\text {rd }}$ \\
\hline Milk yield, $\mathrm{kg}$ & G2 & $48.0 \pm 8.5$ & $48.6 \pm 5.7$ & $46.0 \pm 8.7$ \\
& P2 & $47.1 \pm 8.6$ & $47.9 \pm 7.5$ & $42.6 \pm 8.5$ \\
$\mathrm{~g} \cdot \mathrm{kg}^{-1}$ & & & & \\
fat & G2 & $33.2 \pm 3.8$ & $32.3 \pm 3.5$ & $32.2 \pm 2.8$ \\
& P2 & $32.0 \pm 4.0$ & $32.8 \pm 4.3$ & $30.5 \pm 2.8$ \\
protein & G2 & $30.7 \pm 1.8^{*}$ & $30.7 \pm 1.8$ & $30.6 \pm 2.1$ \\
& P2 & $28.7 \pm 1.5$ & $29.6 \pm 1.5$ & $29.9 \pm 1.6$ \\
lactose & G2 & $50.6 \pm 1.7$ & $51.1 \pm 1.3$ & $50.9 \pm 1.4$ \\
& P2 & $50.5 \pm 1.5$ & $50.9 \pm 1.6$ & $50.6 \pm 1.2$ \\
\hline
\end{tabular}

${ }^{*} P<0.05$ - between groups $\mathrm{G} 2$ and $P 2$ 


\section{Discussion}

Since propylene glycol has been used for many years as an antiketogenic feed additive, and its effect on the energy metabolism and production of dairy cows has been well documented (Nielsen and Ingvartsen, 2004), we used it as a control group. The results of the experiment 1 confirm that glycerol can be as effective as propylene glycol in prevention of ketosis. Similarly, other authors did not find significant differences in the intensity of energy metabolism disturbance between propylene glycoland glycerol-groups of dairy cows (Staufenbiel et al., 2007; Adamski et al., 2011). On the basis of our results, a higher dose of glycerol did not improve energy metabolism in comparison with an energetically lower dose of propylene glycol. Contrary to our results, some authors found a positive effect of increased doses of glycerol on energy metabolism. Wang et al. (2009b) observed a positive linear relationship between glucose concentration and glycerol dose $(100,200,300 \mathrm{~g})$ in cows being 4-63 days in lactation. Nevertheless, some authors also found adverse effects of higher doses of glycerol. Similar doses as in our experiments (430 $\mathrm{g}$ and $840 \mathrm{~g}$ of glycerol) were used in the study of DeFrain et al. (2004). These authors found a tendency towards a slight decrease in glucose together with a rise in BHB after parturition. This finding was supported by Linke et al. (2004) who observed increased BHB in the blood and a higher level of butyrate in the rumen after administering $800 \mathrm{~g}$ of glycerol both in the form of a drench or as part of TMR. The significant differences that we found between the propylene glycol and glycerol groups were in the concentration of total protein at the end of both experiments. The concentration of total protein in blood serum was higher in the glycerol groups in comparison with the propylene glycol groups, but there were no differences in the albumin concentration. We suggest that the higher concentration of globulins in the glycerol groups may be due to increased synthesis of antibodies. We did not find in the literature any information about the influence of glycerol on blood protein synthesis.

Various studies (DeFrain et al., 2004; Farkašová et al., 2007; Wang et al., 2009a; Harzia et al., 2013) indicate that glycerol changes the concentration of individual volatile fatty acids in the rumen, increases the content of propionate and butyrate, and decreases the amount of acetate. In both experiments of our study, the propylene glycol groups showed a numerically higher concentration of acetate and lower concentration of propionate and butyrate as compared with animals that received glycerol; however the differences between groups were relatively small and insignificant. Similar effects of propylene glycol and glycerol on ruminal fermentation were observed by Cozzi et al. (1996) and also Trabue et al. (2007). These authors concluded that the effect of propylene glycol and glycerol on ruminal fermentation is quite similar, with typical reduction of the acetate/propionate ratio. According to our results, the higher dose of glycerol $(1000 \mathrm{ml})$ also failed to increase the butyrate concentration in rumen fluid. Similarly, Kass et al. (2012) found no significant effect of $1 \mathrm{~kg}$ of glycerol on rumen fermentation, but higher amounts ( 2 and $3 \mathrm{~kg}$ ) significantly increased both propionic and butyric acids. On the other hand, Boyd et al. (2013) found increased propionate with $200 \mathrm{~g}$ of glycerol and Abo El-Nor et al. (2010) found decreased acetate and increased butyrate with a glycerol concentration of $36 \mathrm{~g} \cdot \mathrm{kg}^{-1}$ DM. These differences are probably due to the different composition of the total mixed ration.

Milk production did not significantly differ between the glycerol- and propylene glycol groups in our studies. However in both experiments, milk production decreased more in the propylene glycol groups within three months of lactation as compared with the glycerol groups. These results point to some positive effects of glycerol supplementation as compared with propylene glycol. Staufenbiel et al. (2007) also found certain positive effects of glycerol on milk production in comparison with propylene glycol supplementation. Staufenbiel et al. (2007) explained the higher milk production by the higher intake of feed due to better palatability of glycerol as compared with propylene glycol. Our experiments were performed as a field study and it was not possible to monitor intake of feed exactly.

The results of individual studies focusing on the effect of glycerol on milk production are inconsistent. Positive effects of glycerol supplementation on milk production were seen by Farkašová et al. (2007) or Reichel et al. (2007). Nevertheless, Khalili et al. (1997) and Wang et al. (2009b) did not observe any effect of glycerol on milk production or dry matter intake. Chung et al. (2007) observed improved milk production in week 6 after the parturition in cows receiving glycerol for 21 days of lactation. However, the above studies worked with control groups without supplementation of a glucose precursor, whereas our studies compared glycerol with propylene glycol.

Evaluation of individual milk components indicated a significantly higher concentration of protein in group G2 of Experiment 2. The protein 
concentration in milk is affected mainly by the amount of dietary energy, which suggests that this difference could be caused by the application of the higher dose of glycerol. Nevertheless, no significant differences between the glycerol and propylene glycol groups were found at the metabolic level.

\section{Conclusions}

Our results show a similar antiketogenic effect of $300 \mathrm{ml}$ propylene glycol and $500 \mathrm{ml}$ glycerol in high-producing dairy cows in the early lactation period. Although no negative effects of high doses of glycerol $\left(1000 \mathrm{ml} \cdot \mathrm{d}^{-1}\right)$ on metabolism, ruminal fermentation, or liver parenchyma were observed, they did not affect the degree of energy deficiency as compared with the original dose of propylene glycol. The results of this study indicate that glycerol is an appropriate alternative to propylene glycol for cattle producers to prevent energy deficiency and lipomobilization syndrome in the early lactation period.

\section{Acknowledgements}

The work was realized with the support of MSM Project No. 6215712402 'Veterinary Aspects of Foodstuff Safety and Quality’.

\section{References}

Abo El-Nor S., AbuGhazaleh A.A., Potu R.B., Hastings D., Khattab M.S.A., 2010. Effects of differing levels of glycerols on rumen fermentation and bacteria. Anim. Feed Sci. Tech. 162, 99-105

Adamski M., Kupczynski R., Chladek G., Falta D., 2011. Influence ofpropylene glycol and glycerin in Simmental cows in periparturient period on milk yield and metabolic changes. Arch. Tierzucht 54, 238-248

Boyd J., Bernard J.K., West J.W., 2013. Effects of feeding different amounts of supplemental glycerol on ruminal environment and digestibility of lactating dairy cows. J. Dairy Sci. 96, 470-476

Chaney A.L., Marbach E.B., 1962. Modified reagens for determination of urea and ammonia. Clin. Chem. 8, 130-132

Chung Y.H., Rico D.E., Martinez C.M., Cassidy T.W., Noirot V., Ames A., Varga G.A., 2007. Effects of feeding dry glycerin to early postpartum Holstein dairy cows on lactational performance and metabolic profiles. J. Dairy Sci. 90, 5682-5691

Cottyn B.G., Boucque CH.V., 1968. Rapid method for the gas-chromatographic determination of volatile fatty acids in rumen fluid. J. Agr. Food Chem. 16, 105-107

Cozzi G., Berzaghi P., Gottordo F., Gabai G., Andrighetto I., 1996. Effects of feeding propylene glycol to mid-lactating dairy cows. Anim. Feed Sci. Tech. 64, 43-51

DeFrain J.M., Hippen A.R., Kalscheur K.F., Jardon P.F., 2004. Feeding glycerol to transition dairy cows: Effects on blood metabolites and lactation performance. J. Dairy Sci. 87, 4195-4206
Farkašová Z., Reichel P., Kovačocyová K., Hisira V. Kováč G., 2007. The effect of oral feeding glycerol on biochemism of rumen and selected metabolic indices in dairy cows. Rev. Rom. Med. Vet. 17 (2), 297-304

Fisher L.J., Erfle J.D., Lodge G.A., Sauer F.D., 1973. Effects of propylene glycol or glycerol supplementation of the diet of dairy cows on feed intake, milk yield and composition, and incidence of ketosis. Can. J. Anim. Sci. 53, 289-296

Goff J.P., 2006. Major advances in our understanding of nutritional influences on bovine health. J. Dairy Sci. 89, 1292-1301

Harzia H., Kilk K., Ariko T., Kass M., Soomets U., Joudu L., Kaart T., Arney D., Kärt O., Ots M., 2013. Crude glycerol as glycogenic precursor in feed; effects on milk coagulation properties and metabolic profiles of dairy cows. J. Dairy Res. 80, 190-196

Hofírek B., Dvořák R., Němeček L. et al., 2009. Diseases of Cattle (in Czech). CBS, Brno, pp. 1149

Hradecký P., Jagoš P., Janák J., 1978. Gas chromatographic headspace analysis of clinically interesting ketone bodies. J. Chromatogr. 146, 327-332

Kass M., Ariko T., Kaart T., Rihma E., Ots M., Arney D., Kärt O., 2012. Effect of replacement of barley meal with crude glycerol on lactation performance of primiparous dairy cows fed a grass silage-based diet. Livest. Sci. 150, 240-247

Kass M., Ariko T., Samarütel J., Ling K., Jaakson H., Kaart T., Arney D., Kärt O., Otts M., 2013. Long-term oral drenching of crude glycerol to primiparous dairy cows in early lactation. Anim. Feed Sci. Tech. 184, 58-66

Khalili H., Varvikko T., Hissa K., Suvitie M., 1997. The effects of added glycerol or unprotected free fatty acids or a combination of the two on silage intake, milk production, rumen fermentation and diet digestibility in cows given grass silage based diets. Agr. Food Sci. Finland 6, 349-362

Kleen J.L., Hooijer G.A., Rehage J., Noordhuizen J.P., 2004. Rumenocentesis (rumen puncture): a viable instrument in herd health diagnosis. Deut. Tierarztl. Wochenschr. 111, 458-462

Linke P.L., DeFrain J.M., Hippen A.R., Jardon P.W., 2004. Ruminal and plasma responses in dairy cows to drenching or feeding glycerol. J. Dairy Sci. 87, Suppl. 343

Lomander H., Frössling K.L., Gustafsson H., Svensson C., 2012. Supplemental feeding with glycerol or propylene glycol of dairy cows in early lactation - Effects on metabolic status, body condition, and milk yield. J. Dairy Sci. 95, 2397-2408

Nielsen N.I., Ingvartsen K.L., 2004. Propylene glycol for dairy cows: a review of the metabolism of propylene glycol and its effects on physiological parameters, feed intake, milk production and risk of ketosis. Anim. Feed Sci. Tech. 115, 191-213

Pechová A., Illek J., Halouzka R., 1997. Diagnosis and control of the development of hepatic steatosis in dairy cows in the postparturient period. Acta Vet. Brno 66, 235-243

Reichel P., Farkašová Z., Fabini M., Bobus A., Húska M., Seidel H., Kováč G., 2007. Effects of long-term glycerol feeding on health and production of dairy cows during peri-partal period. Rev. Rom. Med. Vet. 17 (2), Suppl. la, 44

Staufenbiel R., Engelhard T., Meyer A., Kanitz W., 2007. Comparison of the metabolic effects of propylene glycol and glycerin in high-producing cows in preventing ketosis. In: Proceedings of the $13^{\text {th }}$ International Conference: Production Diseases in Farm Animals. Leipzig (Germany), p. 166

Stengarde L., Traven M., Emanuelson U., Holtenius K., Hulgren J., Niskanen R., 2008. Metabolic profiles in five high producing Swedish dairy herds with a history of abomasal displacement and ketosis. Acta Vet. Scand. 50, 31 doi:10.1186/1751-0147. 50-31

Trabue S., Scoggin K., Tjandrakusuma S., Rasmussen M.A., Reilly P.J., 2007. Ruminal fermentation of propylene glycol and glycerol. J. Agr. Food Chem. 55, 7043-7051 
Wang C., Liu Q., Huo W.J., Yang W.Z., Dong K.H., Huang Y.X., Guo G., 2009a. Effects of glycerol on rumen fermentation, urinary excretion of purine derivates and feed digestibility in steers. Livest. Sci. 121, 15-20

Wang C., Liu Q., Yang W.Z., Huo W.J., Dong K.H., Huang Y.X., Yang X.M., He D.C., 2009b. Effects of glycerol on lactation performance, energy balance and metabolites in early lactation Holstein dairy cows. Anim. Feed Sci. Tech. 151, 12-20
Wilbert C.A., Prates E.R., Barcellos J.O.J., Schafhäuser J., 2013. Crude glycerin as an alternative energy feedstuff for dairy cows. Anim. Feed Sci. Tech. 183, 116-123

Wildman E.E., Jones G.M., Wagner P.E., Boman R.L., Troutt H.F., Lesch T.N., 1982. A dairy cow body condition scoring system and its relationship to selected production characteristics. J. Dairy Sci. 65, 495-501 